UDC 81-2

DOI https://doi.org/10.32838/2663-6069/2020.2-3/03

Gulustani Zamina

Mingachevir State University

\title{
AREAL FEATURES OF ETHNOTOPONYMS OF TURKIC ORIGIN IN SOUTH AZERBAIJAN
}

The territory of South Azerbaijan is one of the areas where different tribes live and become related. Research and descriptions show that most of the tribes and ethnic groups living in the area were of Turkish origin and are still Turks. Their language, anthropological features and traditions also give grounds to say so. The systematic, scientific study of ethnotoponyms of South Azerbaijan is very important to show that the Turks in that area have always been a local ethnos-people and to explain their role on the stage of history. Also, if you study any of the toponyms in the territory of South Azerbaijan, you will witness that they are of approximately ethnonymic origin. This shows that the study of ethnotoponyms there can lead to interesting scientific results. At the same time, we are witnessing that almost all ethnotoponyms registered in the area have interesting habitat features, which once again highlights the importance and significance of their study.

It is interesting that almost all ethnotoponyms registered in the territory of South Azerbaijan have an area. This is due to the migration of the ethnoses that naturally make them up, and from time to time they grow, divide and settle. The linear analysis of the ethnotoponyms Bayat and Demirchi also confirms the above. Demirchi oykonims were registered in Demirchi, Demirchi ruins in Ardabil district, Lower and upper Demirchi, Demirchili villages, Miyandab and Khojadeh provinces. There are many toponyms related to Demirchi ethnonym in the territory of Northern Azerbaijan, Karabakh, Ganjabasar, Western Azerbaijan, Shirvan Marin. Special names such as "Demirchiler" in Gubadll, Tartar district, "Garademirchi", "Demirchidam", "First and second demirchi", "Beydemirchi" in Barda, Gazakh, Kalbajar districts and etc. are associated with the Demirchi ethnonym.

Subsequent research on Azerbaijani toponymy and ethnonyms has shown that almost all the names of "Domirçi", "demirli" and related lands are of ethnonymic origin. One of the facts proving this is the area feature of the special name "Damirçi". Thus, the fact that there are other settlements in the villages "Damirçi", "Damirçilar", "Damirçidaş", "Temirçi", "Baytemir", "Şorlu Dəmirçi”, "Dəmirçili”, "Temürçə Zilgahı", "Temürçü Qurar” of Iran, Syria, Iraq, Afghanistan, Uzbekistan, Turkmenistan, Bashkortostan, Western Azerbaijan, Georgia and Dagestan and the fact that the population is Turkish reinforces this fact.

Key words: ethnotoponyms, South Azerbaijan, Turkish origin, toponymy, Demirchi.

Introduction. Ethnonyms and ethnotoponyms play an exceptional role in the study of each nation, including the specific name system of that nation. E. Murzayev writes that ethnoses and toponyms formed on their basis are both ancient and, although they have been assimilated, they still leave their traces somewhere [17, p. 48-49].

In this sense, the systematic, scientific study of ethnotoponyms of South Azerbaijan is very important to show that the Turks in that area have always been a local ethnos-people and to explain their role on the stage of history. Also, if you study any of the toponyms in the territory of South Azerbaijan, you will witness that they are of approximately ethnonymic origin. This shows that the study of ethnotoponyms there can lead to interesting scientific results. At the same time, we are witnessing that almost all ethnotoponyms registered in the area have interest- ing habitat features, which once again highlights the importance and significance of their study.

Discussion. There are countless toponyms of Turkic origin in the territory of South Azerbaijan, which are of ethnonymic origin, and there are some of them that have interesting area features. One of them is Bayat ethnotoponym. Bayat ethnotoponym differs from other ethnotoponyms primarily in terms of area quantity [18, p. 140-148].

V. I. Savina also substantiates their Turkic origin by mentioning the names of ethnotoponyms such as Bayar, Bayatlar, Bayatli, Bayatan, Giziltepe Bayat, Bayatansukhta and etc. in connection with the ethnotoponym Bayat in the territory of South Azerbaijan, in the regions of Zanjan, Leristan, Central Iran, Azerbaijan.

Based on V. I. Savina, M. Keyhan informs that Bayats are widespread in the Persian province 
and settled from time to time. Bayat was the name of one of the two tribes of the Gashgay tribe located in the city of Shiraz and surrounding areas. It is also possible to name the descendants of 150 families Bayat Mastali and Bayat Shahverdili.

In his research, I. Chopin also emphasized that the Bayats living in the regions around Shiraz were of the leading tribes and showed that they were of Turkish origin and mixed with other non-Turkic Iranian-speaking tribes [27, p. 238].

Bayats, like other tribes and ethnic groups, play an important role in the ethnogenesis of our people. This tribe, like other ethnic groups, was not excluded from the policy of resettlement and sometimes migration to the countries of the Middle and Near East, especially in Azerbaijan from east to west, from north to south and vice versa, went to Syria, Lebanon, Iraq and other places. According to historical sources, during Amir Teymur's march to the east, most of the Bayats were returned to the territory of South Azerbaijan, some were located in Khorasan, and most were located between Hamadan and Tehran. Even today, most of the Bayats in South Azerbaijan live between Hamadan and Tehran.

O. Afandiyev notes that the Bayats played a special role in the coming to power of the Safavids [2, p. 136; 10 , p. $38 ; 14$, p. $67 ; 21$, p. 34].

Ethnotoponyms such as Ashagi Bayat, Yukhari Bayat in the South Azerbaijan, Giziltepe Bayat in Zanjan, Bayats in Urmia, Bayatli in Bayana, Bayats in Miyana, Atesh Bayat in Makuda and etc. are the remains of Bayats.

Sources indicate that one of the gates of Derbent was named Bayat Gate [24, p. 48; 25, p. 31].

Well-known Turkmen onomatologist S. Ataniyazov argues that bayat in Turkish means "rich" and "noble" and that they live in Afghanistan, Uzbekistan, Turkmenistan, Tajikistan, Azerbaijan, Iran, Turkey, Iraq and Syria considering the Bayat tribe to be one of the largest tribal associations of medieval Oghuz Turkmens [26, p. 54].

T. Ahmadov, E. Ahmadov, A. Bayramov, T. Shukurova and others, speaking about Bayat ethnonym and ethnotoponyms formed on its basis, note that it is of Turkish origin and was moved to the territory of Northern Azerbaijan from the south during the Safavid period [3, p. 31; 4, p. 48; 6, p. 131].

H. Mirzayeva, I. Bayramova and N. Asgarov also support the opinion that the ethnonym Bayat and the place-names formed on its basis reflect the name of the tribe, ethnos of the same name and from time to time they merged with other Turkic-Oghuz and Kipchak tribes $[5$, p. $41 ; 9$, p. $61 ; 20$, p. 57].
As a result of research, G. Geybullayev and N. Asgarov determined that the Bayat tribe was included in the ethnogenesis of the Azerbaijani Turks in such a way that examples such as Bayati-Shiraz, Bayati-Ajam, Bayati-Gachar, Bayati-Isfahan, Choban-Bayati will live forever in our folklore. The genre of "Bayati" as a genre of folklore has been proved to be associated with the name of the Bayat tribe. There are many aspects related to the Bayat tribe in the expressions "calling bayati" and "saying bayati" [14, p. 86-87].

Speaking about theonyms and ethnonyms in Turkish languages, I. Jafarsoylu notes that the ethnonym Bayat is of theonymic origin. In order to prove that the ethnonym Bayat is of theonymic origin, he believes that the ethnonym is related to the beliefs of the ancient Turks, citing Y. Balasagunlu, B. Ogel, F. Sumer, F. Rashidaddin and other sources [21, p. 46-48].

I. Jafarsoylu's general conclusion is that Bayat, which, like many ethnonyms, is considered an ethnonym of Turkish origin, became a theonym in the most ancient times, and then passed to the ethnonym, and from there to the ethnotoponym. This reasoning seems to us to be more correct and reasonable.

"Dəmirçi" ethnotoponym. Demirchi is one of the ethnotoponyms with an interesting and wide range in the territory of South Azerbaijan. T. Ibrahimov writes that one of the largest tribes among the nomadic Shahsevanli tribes of Meshgin is "Dəmirçi" [22, p. 34]. Demirchi oykonims were registered in Demirchi, Demirchi ruins in Ardabil district, Lower and upper Demirchi, Demirchili villages, Miyandab and Khojadeh provinces. There are many toponyms related to Demirchi ethnonym in the territory of Northern Azerbaijan, Karabakh, Ganjabasar, Western Azerbaijan, Shirvan Marin. Special names such as "Demirchiler" in Gubadl1, Tartar district, "Garademirchi", "Demirchidam", "First and second demirchi", "Beydemirchi" in Barda, Gazakh, Kalbajar districts and etc. are associated with the Demirchi ethnonym.

A. Akhundov writes: "The toponyms of both Demirchi and Demirchiler probably originated on behalf of the Turkic-speaking Demirchi tribe. The 13th century historian Shahabaddin Nasri showed that they were descendants of Genghis Khan". According to M. M. Khazani, who lived in the 19th century, they came during the reign of Panahali khan Javanshir, the first khan of the Karabakh khanate of Azerbaijan [1, p. 42].

M. Valiyev, I. Bayramov, P. Musayev, F. Khaligov, G. Mashadiyev, N. Asgarov and others also show that 
the toponym Demirchi and Demirchiler is an ethnotoponym. However, S. Mollazadeh, speaking about the toponyms of the Northern group of Azerbaijan, explains the Oykonim of Demirchi registered in Gabala region in the sense of "the place where the blacksmith is" [23, p. 75].

Conclusions. Subsequent research on Azerbaijani toponymy and ethnonyms has shown that almost all the names of "Dəmirçi", "demirli" and related lands are of ethnonymic origin. One of the facts proving this is the area feature of the special name "Dəmirçi". Thus, the fact that there are other settlements in the villages "Dəmirçi", "Dəmirçilər", "Dəmirçidaş", "Temirçi", "Baytemir", "Şorlu Dəmirçi", "Dəmirçili", "Temürçə Zilgahı", "Temürçü Qurar" of Iran, Syria, Iraq, Afghanistan, Uzbekistan, Turkmenistan, Bashkortostan, Western Azerbaijan, Georgia and Dagestan and the fact that the population is Turkish reinforces this fact. Examining the ethnotoponyms in the territory of South Azerbaijan, we see that almost all of them are of Turkish origin and have a wide distribution area. This was due to voluntary and forced migration, including resettlement and migration policies.

\section{References:}

1. Axundov A. Torpağın köşkündə tarixin izləri. Bakı, 1983. $1363 \mathrm{~s}$.

2. Azərbaycan tarixi. Yeddi cilddə. III cilid. Bak1, 1999. $4889 \mathrm{~s}$.

3. Ohmədov T. Azərbaycanın paleotoponimiyası. Bak1, 1988. $1319 \mathrm{~s}$.

4. Ohmədov E. Azərbaycan etnonimləri. Bak1, 2007. $1568 \mathrm{~s}$.

5. Bayramov I. Qərbi Azərbaycanın türk mənșəli toponimləri. Bakı, 2008. $696 \mathrm{~s}$.

6. Bayramov A. "Kitabi-Dədə Qorqud" toponimləri və Qafqaz. Bakı, 2008. $405 \mathrm{~s}$.

7. Cəlilov F. Qədim türk etnonimləri (Qamət/Kimmer). AOP. Seplusu. Bakı, 1886.

8. Oliyev V. Azərbaycan toponimyası. Bak1, 1999.

9. Әsgərov N. Areal türk onomastik vahidlərinin lingvistik xüsusiyyətləri. Bak1, 2005. $485 \mathrm{~s}$.

10. Obdulqazi B. Şəcereyi-tərqkimə. Bak1, 2002. $194 \mathrm{~s}$.

11. Sümər F. Oğuzlar. Bak1, 1992. 448 s.

12. Hüseynzadə Ә. Müasir Azərbaycan toponimiyasında tayfa adları. Bakı, 1988.

13. Xalıqoo F. Folklor onomastikası. Bak1, 1998. $137 \mathrm{s.}$

14. Гейбуллаев Г. А. К этногенезу азербайджанцев : в 2 т. Баку, 1991. Т. 1. 549 с.

15. Qurbanov A. Azərbaycan dilinin onomologiyas1. Bak1, 1988.

16. Qumilyev L. Qədim türklər. Bak1, 1993.

17. Мурзаев Э. М. Словарь народных географических терминов. Москва : Мысль, 1984. 653 с.

18. Савина В. Я. Этнонимы в топонимии Ирана. Ономастика Востока. Москва, 1980. С. 140-155.

19. Ofəndiyev O. Azərbaycan Səfəvilər dövləti. Bak1, 1993. $301 \mathrm{s.}$

20. Mirzəyev H. Așıq poeziyasında yaşayan adlarımız və tariximiz. Bakı, 1997.

21. Cəfərsoyluv I. Türk dillərinin teonim və etnonimləri. Bakı, 2010.

22. Ibrahimov T. Qaşqaylar. Bakı, 1988.

23. Моллазаде С. М. Топонимия северных районов Азербайджана. Баку, 1979. 407 с.

24. Məşədiyev Q. Qafqaz ərazi və tayfalarının təsviri materialları "məcmuə" sində (SMOMPK) qeydə alınmış Azərbaycan (türk) mənşəli toponimlərin tarixi-linqvistik təhlili. Bakı, 1995.

25. Vəlili M. Azərbaycan (coğrafi-təbii, etnoqrafik və iqtisadi mülahizat). Bakı, 1993.

26. Атаниязов С. Словарь туркменских этнонимов / под ред. П. Азимова, М. Аннанепесова. Ашхабад, 1988. $180 \mathrm{c}$

27. Шопен И. Новые заметки на древние истории Кавказа и его обитателей. Санкт-Петербург, 1866. $501 \mathrm{c}$

\section{Гулустані Заміна. ЛОКАЛЬНІ ОСОБЛИВОСТІ ЕТНОТОПОНІМІВ ТЮРКСЬКОГО ПОХОДЖЕННЯ В ПІВДЕННОМУ АЗЕРБАЙДЖАНІ}

Територія Південного Азербайджану - одна з областей, де живуть $і$ стають спорідненими різні племена. Дослідження показують, що більшість племен та етнічних груп, які мешкали в цій місиевості, були туреиького походження, їхні жителі досі є турками. Їхня мова, антропологічні особливості й традиції також дають підстави для иього висновку. Систематичне наукове вивчення етнотопонімів Південного Азербайджану є дуже важливим для того, щоб показати, щзо турки в иій місиевості завжди були місиевим етносом, і пояснити їхню роль в історії. Крім того, якщо вивчати будь-який із топонімів на території Південного Азербайджану, то можна побачити, щзо вони мають приблизно етнонімічне походження. Це свідчить про те, щзо дослідження етнотопонімів зазначеної місцевості може привести до ијікавих наукових результатів. Водночас ми спостерігаємо, щуо майже всі 
зареєстровані в районі етнотопоніми мають иікаві особливості з огляду на середовище проживання, щчо вкотре підкреслює важливість $і$ значення їх вивчення.

Цікаво, що майже всі етнотопоніми, зареєстровані на території Південного Азербайджану, мають плошу. Це пов'язано з міграчією етносів, які природно населяють їх, час від часу вони ростуть, діляться та осідають. Лінійний аналіз етнотопонімів Баят і Демірчі також підтверджуе сказане. Демірчі ойконіми були зареєстровані в Демірчі, руїнах Демірчі в районі Ардабіл, Нижній і Верхній Демірчі, селах Демірчілі, Міяндаб та Ходжаде. На території Північного Азербайджану, Карабаху, Генджабасару, Західного Азербайджану, Ширвана Маріна є багато топонімів, пов 'язаних з етнонімом Демірчі. Спечіальні назви, такі як «Демірчилер» у Губадлі (татарський район), «Гарадемірчі», "Демірчідам», «Периа і друга демірчі», «Бейдемірчі» в Бардському, Газахському, Калбаджсарському районах тощьо, пов'язані з етнонімом Демірчі.

Подальші дослідження азербайджанської топоніміки та етнонімів показали, що майже всі назви "Дмирмір», «Демірлі» та споріднених земель мають етнонімічне походження. Одним із фактів, що підтверджує ие , є особливість області спеціального найменування «Dәтіrс̧і». Таким чином, той факт,

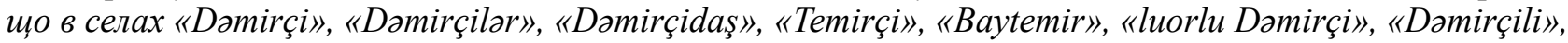
«TeтӥrçəZilgahı», «Tетӥrçü Qurar» єінші населені пункти Ірану, Сирії, Іраку, Афганістану, Узбекистану, Туркменістану, Бамкортостану, Західного Азербайджану, Грузії та Дагестану, підтверджує факт посилення турецького населення.

Ключові слова: етнотопоніми, Південний Азербайджан, турецьке походження, топонімія, Демірчі. 